Abstracta Iranica Abstracta Iranica

Revue bibliographique pour le domaine irano-aryen

Volume 22 | 2001

Comptes rendus des publications de 1999

Sud'by buddizma $v$ Srednej Azii. Po dannym arxeologii. Moscou, Vostočnaja literatura RAN, 1998, 214 p. [Le sort du Bouddhisme en Asie centrale]

Étienne de La Vaissière

(2) OpenEdition

Journals

Édition électronique

URL : http://journals.openedition.org/abstractairanica/36293

DOI : 10.4000/abstractairanica.36293

ISSN : 1961-960X

Éditeur :

CNRS (UMR 7528 Mondes iraniens et indiens), Éditions de l'IFRI

Édition imprimée

Date de publication : 15 mai 2001

ISSN : 0240-8910

Référence électronique

Étienne de La Vaissière, «Sud'by buddizma v Srednej Azii. Po dannym arxeologii. Moscou, Vostočnaja literatura RAN, 1998, 214 p. [Le sort du Bouddhisme en Asie centrale] », Abstracta Iranica [En ligne], Volume 22 | 2001, document 104, mis en ligne le 15 février 2010, consulté le 13 octobre 2020. URL http://journals.openedition.org/abstractairanica/36293; DOI : https://doi.org/10.4000/ abstractairanica.36293

Ce document a été généré automatiquement le 13 octobre 2020

Tous droits réservés 


\title{
Sud'by buddizma $v$ Srednej Azii. Po dannym arxeologii. Moscou, Vostočnaja literatura RAN, 1998, 214 p. [Le sort du Bouddhisme en Asie centrale]
}

\author{
Étienne de La Vaissière
}

Cette publication a pour intérêt de rassembler en un seul ouvrage les principaux résultats de toutes les fouilles soviétiques de sites bouddhiques dans l'Asie centrale iranophone et turcophone. Le plan est géographique. La Bactriane du nord et le Tokharestan se taillent la part du lion, en raison des travaux de l'A., spécialiste de la région sous les Kouchans (voir Abs. Ir., 10, c.r. $\mathrm{n}^{\circ}$ 213) mais sont également traités les sites bouddhiques de Merv, de Sogdiane, du Ferghana et du Semireče. Sont ensuite abordées : les trouvailles principales faites sur ces sites, une synthèse historique sur le sort du bouddhisme dans la région et enfin un excursus sur l'architecture bouddhiste. Nombreuses illustrations et photos dans le texte.

\section{INDEX}

Thèmes : 3.1. Est de l'Iran 
AUTEURS

ÉTIENNE DE LA VAISSIÈRE

ENS - Paris 